\title{
IS ENTERPRISE RISK MANAGEMENT A VALUE ADDED ACTIVITY?
}

\author{
Mojca Marc, Danijela Miloš Sprčić, Marina Mešin Žagar
}

\section{Introduction}

Severe consequences of the global financial crisis resulted in re-thinking the risk management processes and approaches. OECD (2009), BIS (2008), FSA (2008) and IIF (2007) suggested that corporate risks should be "high on the agenda" of every organization, highlighting the need for a comprehensive (enterprise-wide) risk management framework. What has been realized in the aftermath of the global financial crisis is that a failure to transmit information about risk exposures can be attributed to the traditional silo-based risk management (TRM) (OECD, 2009). In TRM risks are managed in isolation by business unit managers with little oversight or communication of how particular risk management decisions affect other corporate risks and corporate strategy. Consequently, more and more companies around the world are moving away from TRM to a more holistic approach known as enterprise risk management (ERM) (CGMA, 2015).

To bring benefits in terms of value protection and value enhancement, ERM should be integrated into the corporate strategy, decision making process and corporate culture (Lam, 2003; Meulbroek, 2002; Nocco \& Stulz, 2006; Segal, 2011). Identification of key risk factors and determination of their importance by using risk assessment matrix is very important if risk management is used as a strategic tool (Vacik, Fotr, Špaček, \& Souček, 2014). Nocco and Stulz (2006) claim that ERM increases company value by decreasing the probability of low-tailed outcomes. ERM does this by enabling companies transfer non-core risks, like financial risks, to other market participants and to undertake more core-business risks which the firm has a competitive advantage in managing. ERM thus encompasses both, strategic risk taking as well as deliberate risk hedging, implying a balance between the dual nature of risk (threats vs opportunities) to attain value creation.

The existing ERM literature is rich in textbooks (e.g. Fraser \& Simkins, 2010; Lam, 2003; Segal, 2011), as well as in review and professional papers (Lam, 2001; Meulbroek, 2002; Nocco \& Stulz, 2006), which claim, in a very straightforward way, that because ERM offers a more comprehensive way of managing risks it contributes to value creation in companies. However, academic research on ERM is still in its infancy (Bromiley, McShane, Nair, \& Rustambekov, 2014). Empirical research that explores if and how ERM actually affects company performance and creates value is scarce. Most studies explore ERM's influence on the performance and market value of financial companies, mostly insurance companies (e.g. Baxter, Bedard, Hoitash, \& Yezegel, 2013; Eckles, Hoyt, \& Miller, 2014; Grace, Leverty, Phillips, \& Shimpi, 2015; Hoyt \& Liebenberg, 2011; McShane, Nair, \& Rustambekov, 2011), and there are just a few studies addressing ERM's effects in non-financial companies (e.g. Gordon, Loeb, \& Tseng, 2009).

According to the existing ERM literature, the overarching objective of ERM is to contribute to the fundamental value creation process. Yet, none of the existing studies explore if ERM actually increases the fundamental company value or is it just the latest fashion in management tools. This is the question we try to answer. The absence of empirical evidence about ERM's impact on the company's fundamental goal - shareholders' value enhancement - is a limitation to the growth and development of ERM as a discipline. Considering that ERM has the longest tradition in the United States (Lam, 2001; Meulbroek, 2002), we investigate the effects of ERM in large U.S. companies, but the implications of this research are both regionally and internationally relevant. 
This paper thus provides evidence on the ERM's long-term impact on a set of fundamental value drivers of S\&P 500 nonfinancial companies, over the period from 2003 to 2012. Besides providing additional evidence on ERM effects in non-financial companies, this study offers a different approach in examining ERM by exploring if ERM affects a company's fundamental value and not its market value like other studies do. Also, unlike other studies, it shows evidence of ERM's long-term impact. For that purpose, we measure the number of years ERM is in place. Other studies have used an ERM index (Gordon et al., 2009), a dummy variable (Hoyt \& Liebenberg, 2011; Eckles et al., 2014), the S\&P's ERM rating (Baxter et al., 2013; McShane et al., 2011) or an ERM level of sophistication (Grace et al., 2015). These measures do not take into account the number of years a company has spent in implementing and using ERM. We believe this is important as ERM is not an overnight process and practitioners usually state that it takes from three to five years to develop a mature ERM system within an organization (Fraser \& Simkins, 2010). Therefore, it seems reasonable to assume that companies using ERM for a longer time will experience more of its benefits.

The paper is organized as follows. In section 1 , we provide a review of the existing literature and develop our hypothesis about ERM's effects on a set of fundamental value determinants. Section 2 describes the econometric model and variables employed, as well as sampling and data collection. In section 3, we present the results of our empirical analysis. The last section discusses the results and concludes the paper.

\section{Literature Review and Hypothesis Development}

According to the existing literature, ERM is an important element of an effective corporate governance system that encompasses activities and strategies which enable the company to identify, measure, reduce or exploit, as well as to control and monitor the exposure to various types of corporate risks - strategic, financial, operational, reporting as well as compliance risks. The primary aim of ERM is to increase the likelihood that strategic objectives are realized and shareholders' value is preserved and enhanced. However, by adopting a systematic and integrated approach to corporate risk management, ERM should improve corporate sustainability and lower a company's overall risk of failure, making positions for other stakeholders more secure and valuable. Although many authors explored the effects of hedging as a risk management technique and found that hedging stabilizes expected earnings and cash flows, reduces the probability of financial distress and agency cost of debt (Campbell \& Kracaw, 1987; Dolde, 1995; Haushalter, 2000; Haushalter, Heron, \& Lie, 2002; Mian, 1996; Minton \& Schrand, 1999; Smith \& Stulz, 1985; Stulz, 1984), increases the growth potential of the company (Froot, Scharfstein, \& Stein, 1993; Gay \& Nam, 1998; Géczy, Minton, \& Schrand, 1997; Haushalter, 2000; Haushalter et al., 2002; Hoshi, Kashyap, \& Scharfstein, 1991; Minton \& Schrand, 1999; Miloš Sprčić \& Šević, 2012; Nance, Smith, \& Smithson, 1993), and consequently increases the company's value, empirical evidence on ERM effects in companies is relatively scarce.

Five empirical studies investigating ERM's effects on companies' financial performance and market values have been conducted so far. The results of these studies are mixed; however evidence of positive ERM effects is predominant. The study by Gordon et al. (2009) revealed that in high-performing ERM companies, the effectiveness of ERM is moderated by industry competition, complexity, size and board monitoring. This suggests that contingency variables are taken more seriously by highperformance companies in their implementation of ERM. Hoyt and Liebenberg (2011) found a positive effect of ERM implementation on a company's market value measured by Tobin's Q. Baxter et al. (2013) found that higher ERM quality is associated with greater complexity, less resource constraint, and better corporate governance in financial services firms. Controlling for such characteristics, they found that higher ERM quality is associated with improved accounting performance. Eckles et al. (2014) found that insurance companies with ERM experience a reduction in stock return volatility and that operating profits per unit of risk (ROA/return volatility) increase after ERM adoption, indicating a positive effect of ERM on the company's performance. The only study suggesting that ERM does not influence a company's value is McShane et al. (2011). Although they find a positive relationship between an insurance company's 
S\&P ERM rating and its market value as the rating increases from 'weak' to 'adequate with a positive trend', they do not find additional increases in market value as the rating moves towards the more sophisticated ERM levels. This means that better TRM increases market values, but moving from TRM to ERM is not perceived by investors as a value added activity.

The current literature did not develop formal models of mechanisms through which ERM is supposed to affect a company's value. We therefore turn to models of corporate valuation as our starting point. Two commonly used models of absolute corporate value are the residual income model $(\mathrm{RI})$ and the discounted cash-flow model (DCF). The RI model describes the value of a company as:

$$
V_{C}=B V E_{0}+\sum_{t=1}^{\infty} \frac{R I_{t}}{\left(1+r_{c}\right)^{t}}
$$

where: $V_{C}=$ fundamental (intrinsic) value of company; $B V E_{0}=$ current book value of equity; $R I_{t}=$ residual income in period $t ; r_{C}=$ the cost of capital.

The value of a company is increased either through a higher expected residual income and/ or a lower cost of capital, which is the discount rate in the model. Residual income is defined as the "surplus" that the company achieves within a certain period after it has settled all operating costs, including the cost of equity. Residual income is usually calculated by using one of the following formulas:

1. RESIDUAL INCOME $=$ Net Operating Profit after Taxes - (Invested Capital x Weighted Average Cost of Capital)

2. RESIDUAL INCOME = Invested Capital $x$ (Return on Invested Capital - Weighted Average Cost of Capital).

For a company to create value, the rate of return on invested capital should be above the total cost of capital. The value of residual income depends on the units of capital invested as well, so if the value of invested capital is greater, residual income is higher, assuming that capital is invested in profitable investments.

The DCF model determines the company's value in the following way:

$$
V_{C}=\frac{F C F_{0} \times(1+g)}{W A C C-g}
$$

where: $V_{C}=$ present value of the company; $F C F_{0}=$ current free cash flow; $g=$ expected growth rate of future FCF; WACC = weighted average cost of company's capital.

In this model, a company's value is a function of three variables: 1) free cash flows from existing investments, 2) expected growth rate that determines the value of future cash flows, and 3) weighted average cost of capital. A company's value will increase with larger free cash flows, higher growth rates and lower cost of capital. Based on both models it is straightforward to see that ERM adoption could affect company's value either by affecting its cash flows or by affecting its cost of capital. In this paper we investigate how ERM affects variables related to cash flows and leave the effects on cost of capital for future research. Apart from the cost of capital, we can thus identify five corporate value determinants:

1. Net operating profit after taxes (NOPAT),

2. Return on invested capital (ROIC),

3. Invested capital (IC),

4. Free cash flows from existing investments (FCF),

5. Expected growth rate that determines the value of the future cash flows ( $g$ rate).

The primary aim of ERM is to increase the likelihood that company's strategic objectives are realized and shareholders' value is preserved and enhanced. To achieve this goal, ERM considers the interactive effects of different risk events and offers a balance between the dual nature of risk - ensuring effective protection from threats and seizing the opportunities. Therefore, if ERM is implemented as a strategic tool, sales revenues of the company should grow because of better identification and undertaking of profitable opportunities. For example, thoughtful risk taking activities could provide new market opportunities, new customers, or the development of new innovative products, that can increase the value of sales. On the other hand, reasoned hedging of risks that the company does not want to carry over can provide stabilization of operative revenues and/or costs. For example, concluding forward contracts with key suppliers can reduce the cost of raw materials and ancillary services. This is consistent with the macro benefits of ERM described by Nocco and Stulz (2006). They claim that companies can earn a long-run competitive advantage 
through ERM since it enables them to transfer the non-core risks, like financial risks, which can be transferred effectively through derivative instruments. Due to this possibility, the company can undertake more core business risks that the firm has competitive advantage in bearing. We can therefore assume that companies with ERM should be more effective in undertaking business risks necessary to achieve their goals, while they are better protected from financial risks. By creating synergies between different risk management activities ERM improves capital efficiency. Hence, we expect that ERM is positively related to NOPAT, ROIC, and the expected growth rate.

On the other hand, ERM could reduce the problem of underinvestment in financially constrained companies. Froot et al. (1994) demonstrated how the principles of the pecking order theory could help develop a coherent riskmanagement strategy. In general, the supply of internally generated funds does not equal the investment demand for funds - sometimes there is an excess supply, and sometimes there is less than needed. Due to high cost of external financing, this imbalance shifts investment away from the optimal level. Risk management can reduce this imbalance and the resulting investment distortion as it enables companies to better align their demand for funds with their internal supply of funds. Froot et al. (1994) argue that risk management allows companies to transfer funds from situations in which they have an excess supply to situations in which they have a shortage. In this respect, ERM should act in a similar way and we therefore argue that ERM increases the invested capital, because it stabilizes and increases operative earnings and cash flows. Lower volatility of expected cash flow increases the probability of having sufficient internal funds for planned investments and eliminates the need either to cut profitable projects or to pay high transaction costs for external funding. We therefore expect to find that ERM is positively related to the level of IC, as well as to the size of cash flows (FCF). Our research hypothesis is thus the following:

H1: ERM positively affects the proposed set of fundamental value determinants.

\section{Method}

We test our hypothesis empirically with a reduced form model, where value determinants are related to ERM use, controlling for other factors that can affect the value determinants.

$$
\begin{aligned}
& \text { Value determinant }_{j}= \\
& =f(E R M, \text { control variables })
\end{aligned}
$$

where Value determinant ${ }_{j}$ are NOPAT, IC, ROIC, FCF, and the expected growth rate $g$.

We exploit the panel structure of the collected data and apply the difference-indifference logic to identify the effects of ERM on value determinants. By using the fixedeffects (FE) approach to estimate our model we eliminate all company-specific unobserved effects, which are constant in time and might affect our dependent variables, and thus minimize the omitted variable bias (Wooldridge, 2002). We also include exogenous time-effects to control for changes in macroeconomic conditions that are the same for all companies in the sample. Compared to a straightforward pooled OLS estimation, FE produces unbiased coefficients and standard errors that are corrected for the correlation of idiosyncratic error term over time for a given company. Our econometric model is thus the following:

$$
\begin{aligned}
& V D_{i t}=\beta_{1} \text { ERM }_{i t}+\sum_{1}^{k} \beta_{k} \times \\
& \times \text { Control variable } \text { vit }+u_{i}+\mu_{t}+\varepsilon_{i t}
\end{aligned}
$$

where $V D_{i t}$ are value determinants NOPAT ${ }_{i t}$ ' $F C F_{i t}, I C_{i t}, R O I C_{i t}$, and the g_rate ${ }_{i t}$ of company $i$ in year $t ; E R M_{i t}$ is 1 if company $i$ has ERM in year $t$ and 0 otherwise; Control variables ${ }_{i t}$ are Size $_{i t}$, Leverage $_{i t}$, Growth opportunities ${ }_{i t}$, Dividend policy $_{i{ }^{\prime}}$ and Volatility ${ }_{i t}$ of company $i$ in year $t ; u_{i}$ are company-specific effects, $\mu_{t}$ are year-specific effects, and $\varepsilon_{\text {it }}$ are idiosyncratic error terms.

A positive significant coefficient $\beta_{1}$ in equation (4) indicates that ERM is associated with a higher value of a particular value determinant. The coefficient is predicted to be positive for all value determinants. We run the model also by including indicator variables for the duration of ERM instead of the dummy variable ERM. In this case, a positive significant coefficient implies that ERM increases companies' value determinants after a certain period of time: 


$$
\begin{aligned}
& V D_{i t}=\beta_{1} 1_{-} E_{R} M_{i t}+\beta_{2} 2_{-} E R M_{i t}+\cdots \\
& \cdots+\beta_{10} 10_{-} E R M_{i t}+\sum_{1}^{k} \beta_{k} \times \\
& \times \text { Control variable } \text { kit }+u_{i}+\mu_{t}+\varepsilon_{i t}
\end{aligned}
$$

For example, a positive significant coefficient $\beta_{5}$ (in equation 5) indicates that ERM affects the value driver after five years of use.

\subsection{Variables' Measurement}

One of the major challenges of ERM studies is how to identify companies that employ ERM. To determine whether a company uses ERM we followed the methodology used by Gordon et al. (2009), Hoyt and Liebenberg (2011), and Eckles et al. (2014). We performed a thorough search of companies' SEC filings for every company in the sample and analyzed in detail sections of filings where keywords related to ERM appeared. We took into account the following elements and characteristics of ERM: integration of risks identification, analysis, measurement and management process, active involvement of the board in the ERM process, integration of ERM into corporate strategy and corporate culture, organization of ERM workshops, calculation of probability and significance of identified risks, creation of a Risk map, and appointment of a Risk Champion (Risk Officer). This allowed us to determine in which year the company implemented ERM. Additionally, as a means of a double-check, we did a search in Lexis-Nexis and PR Newswire for any news announcements about ERM for each of the companies in the sample, as well as a Google search, in order to look for any additional information. Examples of ERM and non-ERM companies are presented in the Appendices A and B. Since there was no evidence of discontinued use of ERM, we measure the duration of ERM programs (ERM years) by counting the number of years since ERM was adopted.

The variables used to measure the value determinants are calculated similarly to the existing literature. Net operating profit after taxes (NOPAT) is determined as earnings before interest and taxes (EBIT) less taxes. Total invested capital (IC) is determined as working capital plus fixed assets and investments. ROIC is the return on invested capital, calculated as the ratio of NOPAT to IC. The expected growth rate (g_rate) is calculated as the ratio of the change in invested capital to the level of IC (Damodaran, 2012). Free cash flow $(F C F)$ is calculated as NOPAT plus depreciation and amortization minus capital and operative expenditures. To correct for the effect of different magnitudes, we use natural logarithms of NOPAT, IC, and FCF.

We control for a set of variables that potentially influence the value determinants: company size, financial structure (leverage), growth opportunities, dividend policy, and volatility. We measure company size with the natural logarithm of total assets to correct for the effect of different magnitudes and to reduce the effect of skewness in the distribution (Size). Because larger companies can exploit the economies of scale better, we believe that company size is positively related to its fundamental value. However, some studies found an insignificant or even negative effect of size on companies' value (Allayannis \& Weston, 2001; McShane et al., 2011). Therefore, we make no a priori prediction regarding the effect of company size on its value determinants.

Leverage controls for the relation between a company's capital structure and its value determinants. We measure Leverage as the ratio of the book value of long-term debt to the market value of equity (Allayannis \& Weston, 2001; Titman \& Wessels, 1988). According to the Modigliani-Miller's trade-off theory (Modigliani \& Miller, 1963), an increase in the financial leverage has a positive effect on the cost of capital and a firm's value, as long as the present value of tax savings is greater than the cost related to the increased probability of bankruptcy. However, increasing the value of debt above the optimal level raises the probability of bankruptcy, which increases the cost of financial difficulties and the cost of capital, and decreases the company's value. The predicted sign of the relation between leverage and value determinants is therefore a priori ambiguous.

By combining the approaches of DeMarzo and Duffie (1991), Gordon et al. (2009), and McWilliams and Siegel (2000) we proxy the growth opportunities with a historical $(t-1)$ ratio, calculated as capital expenditures plus R\&D expenditures, all divided by sales (Growth opp). More growth opportunities are likely to increase a company's value determinants, therefore, we predict a positive relation between them. 
Following Hoyt and Liebenberg (2011), we include a proxy of the dividend policy as a control variable. We use a dividend payment indicator, which has value 1 if dividends were paid out in a particular year $t$, and 0 otherwise (Dividend policy). Again, we cannot make predictions regarding the expected sign as, according to the corporate finance theory, dividends can affect company's value both positively and negatively. Positively, because a dividend payment represents an indicator of a company's financial strength to investors expecting part of the required return in the form of dividends. However, if the investors think that the money paid out through dividends could be reinvested into profitable investment opportunities, thereby adding value to shareholders wealth, a dividend payment can reduce a company's value.

We include volatility among explanatory variables to control for differences in volatility between ERM and non-ERM companies. The effect of ERM is thus estimated conditional on volatility. Volatility is measured with the coefficient of variation of quarterly EBIT (Liebenberg \& Hoyt, 2003), calculated as the ratio of EBIT's standard deviation and its mean annual value. Tab. 1 summarizes the measurement of our variables.

\section{Tab. 1: Measurement of variables}

\begin{tabular}{l|l}
\multicolumn{1}{c|}{ Variables: } & \multicolumn{1}{c}{ Definitions: } \\
\hline ERM & 1 if company has ERM, 0 if company does not have ERM \\
\hline ERM years & Number of years a company is using ERM \\
\hline NOPAT & LN (EBIT less income taxes), where EBIT is earnings before interest and taxes \\
\hline FCF & $\begin{array}{l}\text { LN (NOPAT plus depreciation and amortization minus capital and working capital } \\
\text { expenditures) }\end{array}$ \\
\hline IC & LN (Working capital plus fixed assets and investments) \\
\hline ROIC & NOPAT to total invested capital (NOPAT to IC) \\
\hline g_rate & The change in invested capital (IC) to the level of invested capital (IC) \\
\hline Size & LN of total assets \\
\hline Leverage & The book value of long-term debt to the market value of equity \\
\hline Growth opp & Capital and R\&D expenditures to sales (historical - one year lagged) \\
\hline Dividend policy & 1 if company paid out dividends, 0 if company did not pay out dividends \\
\hline Volatility & $\begin{array}{l}\text { Coefficient of variation of quarterly EBIT, where EBIT is earnings before interest } \\
\text { and taxes }\end{array}$ \\
\hline
\end{tabular}

\subsection{Sampling and Data Collection}

The research is conducted on the U.S. market among 258 non-financial companies that were constituents of the S\&P 500 index from 2003 to 2012. The industry structure of the sample at 2-digits SIC Code is presented in the Appendix (Tab. A1). From the Compustat North America database we collected accounting data for the 258 companies in our sample for the 20032012 period, and constructed a panel with 2,580 company-year observations. We also collected data from the year 2002 to calculate variables entering the models with a one-year lagged value. We eliminated cases with logically impossible values (e.g. total assets lower than current assets, total debt lower than long-term debt etc.), cases with 'false positive' ratios produced by a negative denominator and numerator, and cases with negative shareholder's equity.

By the end of the observed period, 176 companies from the sample were identified as having implemented an ERM system, while 82 companies have not implemented ERM. Out of the 176 ERM companies almost half have implemented it in 2010 (33 percent of the total sample). Among the companies in the sample, only 11 had an ERM system in all of the observed years. This indicates that ERM is a rather novel 
Tab. 2: Descriptive statistics of variables used in models

\begin{tabular}{l|r|r|r|r|r}
\multicolumn{1}{c|}{ Variable } & \multicolumn{1}{c|}{ Obs } & \multicolumn{1}{c|}{ Mean } & \multicolumn{1}{c|}{ Std. Dev. } & \multicolumn{1}{c}{ Min } & \multicolumn{1}{c}{ Max } \\
\hline ERM & 2,580 & 0.291 & 0.454 & 0 & 1 \\
\hline ERM years & 2,580 & 0.975 & 1.963 & 0 & 10 \\
\hline NOPAT & 2,515 & 6.983 & 1.151 & 0 & 10.742 \\
\hline FCF & 2,307 & 6.725 & 1.289 & 1.386 & 10.659 \\
\hline IC & 2,506 & 9.205 & 1.151 & 5.901 & 12.505 \\
\hline ROIC & 2,506 & 0.122 & 0.093 & -0.331 & 2.096 \\
\hline g_rate & 2,504 & 0.023 & 0.107 & -1.427 & 0.612 \\
\hline Size & 2,580 & 9.524 & 1.141 & 6.847 & 13.590 \\
\hline Leverage & 2,580 & 0.274 & 0.710 & 0 & 24.252 \\
\hline Growth opp & 1,705 & 0.110 & 0.095 & 0 & 0.863 \\
\hline Dividend policy & 2,580 & 0.813 & 0.390 & 0 & 1 \\
\hline Volatility & 2,579 & 7.486 & 8.733 & -25.121 & 149.200 \\
\hline
\end{tabular}

approach to corporate risk management and that its broader implementation started during or after the global financial crisis. In total, we have 751 (c. 30\%) company-year observations with ERM. Tab. 2 shows the descriptive statistics for variables used for estimation of the models.

\section{Results}

Results presented in Tab. 3 do not offer strong support for our predictions regarding the associations between ERM and fundamental value drivers. In the estimated models, ERM has a positive significant effect only on the level of IC (column 3; $p<.05$ ). Specifically, the results indicate that companies with ERM have on average a 2 percent higher invested capital compared to companies without ERM-controlling for size, leverage, growth opportunities, dividend policy, volatility, and taking into account companies' individual and year effects. Contrary to our expectations, ERM has a significant negative effect on the growth rate $g$ (column $5 ; p<.05$ ). The results suggest that ERM companies have on average a 1.9 percentage point lower expected growth rate compared to companies without ERM. Since we proxied the expected growth rate $g$ with a ratio of the IC change to the IC level, we can conclude that ERM seems to decrease the change in invested capital. This also implies that either the effect of ERM on ROIC or its effect on the reinvestment rate is negative. The estimated effect on ROIC is indeed negative, although statistically insignificant (column 4). Moreover, consistent with this are also the signs and sizes of ERM effects on NOPAT (negative) and IC (positive). The effect on NOPAT is not significant, but contrary to our expectations, the sign is negative. Taken together, our results indicate that ERM companies are more conservative in their investment strategies. Companies that implemented ERM have more invested capital in general, however, they seem to invest less additional capital (and in possibly low-risk/low-return projects), thus resulting in smaller expected growth rates.

To get more insight into our benchmark results, we need to know i) in what way companies that ultimately implemented ERM were different from companies that never implemented ERM, and ii) how were the companies with ERM different after ERM implementation. For this purpose, we first test the differences in value determinants on a restricted sample of company-year observations without ERM, presented in Tab. 4. The results show that the average $I C$ and $g \_$rate of companies, which later implemented ERM, were not different from the ones in companies that never implemented $\mathrm{ERM}$, in a statistically significant way $(p>0.05)$. On the other hand, NOPAT, FCF, and ROIC were on average higher in companies that later implemented ERM. The t-tests of control 
Tab. 3: Benchmark model regression results

\begin{tabular}{|c|c|c|c|c|c|}
\hline & (1) & (2) & (3) & (4) & (5) \\
\hline & NOPAT & $F C F$ & IC & ROIC & $g$ rate \\
\hline \multirow[t]{2}{*}{$E R M$} & -0.018 & -0.047 & $0.020^{*}$ & -0.007 & $-0.019^{*}$ \\
\hline & $(-0.43)$ & $(-0.92)$ & $(2.45)$ & $(-1.24)$ & $(-2.10)$ \\
\hline \multirow[t]{2}{*}{ Size } & $0.812^{* \star *}$ & $0.645^{\star \star *}$ & $1.085^{\star \star \star}$ & $-0.044^{* *}$ & $0.030^{*}$ \\
\hline & $(5.14)$ & $(5.40)$ & (72.57) & $(-3.08)$ & $(1.97)$ \\
\hline \multirow[t]{2}{*}{ Leverage } & $-0.182^{\star *}$ & -0.153 & 0.006 & $-0.030^{\star}$ & -0.015 \\
\hline & $(-3.20)$ & $(-1.43)$ & $(0.79)$ & $(-2.42)$ & $(-0.90)$ \\
\hline \multirow[t]{2}{*}{ Growth opp. } & $-1.649^{* *}$ & $-1.671^{* *}$ & 0.069 & $-0.239^{* * *}$ & 0.065 \\
\hline & $(-2.62)$ & $(-3.29)$ & (1.29) & $(-4.20)$ & $(0.74)$ \\
\hline \multirow[t]{2}{*}{ Dividend policy } & 0.128 & 0.053 & 0.007 & $0.026^{*}$ & 0.009 \\
\hline & (1.72) & $(0.75)$ & $(0.43)$ & $(2.36)$ & $(0.48)$ \\
\hline \multirow[t]{2}{*}{ Volatility } & $0.009^{* * *}$ & $0.007^{* * *}$ & 0.000 & $0.001^{* * *}$ & 0.001 \\
\hline & $(4.43)$ & (3.68) & $(0.62)$ & (3.79) & $(1.06)$ \\
\hline \multirow[t]{2}{*}{ Constant } & -0.835 & 0.679 & $-1.087^{* * *}$ & $0.517^{* * *}$ & -0.254 \\
\hline & $(-0.57)$ & $(0.62)$ & $(-8.07)$ & $(4.02)$ & $(-1.87)$ \\
\hline Observations & 1,657 & 1,612 & 1,644 & 1,644 & 1,644 \\
\hline No. clusters & 178 & 178 & 172 & 172 & 172 \\
\hline $\mathrm{R}^{2}$ _within & 0.435 & 0.216 & 0.941 & 0.210 & 0.031 \\
\hline
\end{tabular}

Source: own

Note: FE estimator, company and year effects included; t-statistics in parentheses based on cluster-robust $S E ;{ }^{*} p<0.05$, ${ }^{* *} p<0.01,{ }^{* * *} p<0.001$.

variables are significant for all of the, except Leverage, and confirm that these variables should be controlled for in regressions.

Next, we estimate the benchmark model on a restricted sample with only ERM-companies and thus test if the value determinants in these companies were different after ERM implementation. The results in Tab. 5 again show a positive significant difference only for the level of IC: after ERM implementation, companies with ERM had on average a 2.3 percent higher IC compared to periods before they implemented ERM. This again indicates that the effects of ERM programs are mostly associated with increasing the level of $I C$, while the effects on other value drivers are rather small and possibly even negative.

We further investigate the effects of ERM by replacing the dummy ERM variable with indicator variables for the number of years a company is using ERM (Tab. 6). The coefficients show differences with respect to observations without ERM. Our results indicate that after one or two years of using ERM, IC is increased by around 0.02 percent (the coefficient for two years is only marginally statistically insignificant, $p=0.0526$ ). In the following years, the effect is mostly slightly above or below this number, which indicates that the duration of the ERM program does not affect the IC, however, the adoption does. Also after one or two years of using ERM, ROIC seems to drop by around 0.9 percentage point (the coefficients are marginally statistically insignificant at $p=0.0514$ and $p=0.124)$. The negative effects on ROIC seem to become smaller in later years. Also the growth rate is on average 2.8 percentage points lower after two years of using ERM compared to observations without ERM. On the other hand, the estimations for FCF suggest that the 


\section{Ekonomika a management}

Tab. 4:

ERM companies (before ERM implementation) compared to non-ERM companies - $t$ test

\begin{tabular}{l|r|r|r|r|r|r}
\multicolumn{1}{c|}{ Variable } & $\begin{array}{c}\text { ERM } \\
\text { (Mean) }\end{array}$ & \multicolumn{1}{c|}{$\begin{array}{c}\text { ERM } \\
\text { (SD) }\end{array}$} & $\begin{array}{c}\text { NonERM } \\
\text { (Mean) }\end{array}$ & $\begin{array}{c}\text { NonERM } \\
\text { (SD) }\end{array}$ & \multicolumn{1}{c|}{ t test } & $p$ value \\
\hline NOPAT & 6.954 & 1.088 & 6.756 & 1.210 & -3.610 & $0.000^{*}$ \\
\hline FCF & 6.712 & 1.229 & 6.510 & 1.306 & -3.213 & $0.001^{*}$ \\
\hline IC & 9.135 & 1.090 & 9.041 & 1.245 & -1.687 & 0.092 \\
\hline ROIC & 0.131 & 0.113 & 0.109 & 0.073 & -4.856 & $0.000^{*}$ \\
\hline g_rate & 0.028 & 0.115 & 0.024 & 0.105 & -0.843 & 0.399 \\
\hline Size & 9.469 & 1.071 & 9.319 & 1.212 & -2.820 & $0.005^{*}$ \\
\hline Leverage & 0.285 & 0.993 & 0.236 & 0.451 & -1.295 & 0.195 \\
\hline Growth opp & 0.108 & 0.100 & 0.126 & 0.099 & 3.022 & $0.003^{*}$ \\
\hline Dividend policy & 7.379 & 7.847 & 6.625 & 7.236 & -2.114 & $0.035^{*}$ \\
\hline Volatility & 0.810 & 0.393 & 0.762 & 0.426 & -2.477 & $0.013^{*}$ \\
\hline
\end{tabular}

Note: ${ }^{*} p<0.05$

\section{Tab. 5: ERM companies (after ERM implementation) compared to before implementation}

\begin{tabular}{l|c|c|c|c|c} 
& $\mathbf{( 1 )}$ & $\mathbf{( 2 )}$ & $\mathbf{( 3 )}$ & $\mathbf{( 4 )}$ & $\mathbf{( 5 )}$ \\
\cline { 2 - 6 } & $\mathbf{N O P A T}$ & $\mathbf{F C F}$ & $\mathbf{I C}$ & $\mathbf{R O I C}$ & $\mathbf{g}$ rate \\
\hline ERM & -0.000 & -0.084 & $0.023^{*}$ & -0.000 & -0.008 \\
\hline Size & $(-0.01)$ & $(-1.30)$ & $(2.24)$ & $(-0.07)$ & $(-0.65)$ \\
\hline & $0.866^{* * *}$ & $0.741^{* * *}$ & $1.097^{* * *}$ & $-0.041^{*}$ & 0.020 \\
\hline Leverage & $(3.94)$ & $(4.74)$ & $(55.28)$ & $(-2.10)$ & $(1.01)$ \\
\hline & $-0.197^{*}$ & -0.153 & 0.018 & $-0.073^{* * *}$ & -0.048 \\
\hline Growth opp. & $(-2.35)$ & $(-1.45)$ & $(0.94)$ & $(-5.26)$ & $(-1.89)$ \\
\hline & $-0.822^{*}$ & $-1.361^{*}$ & $0.154^{*}$ & $-0.153^{* *}$ & $0.200^{*}$ \\
\hline Dividend policy & $(-2.15)$ & $(-2.47)$ & $(2.41)$ & $(-2.86)$ & $(2.03)$ \\
\hline & 0.185 & 0.091 & 0.024 & $0.033^{*}$ & -0.001 \\
\hline Volatility & $(1.83)$ & $(1.19)$ & $(1.82)$ & $(2.20)$ & $(-0.02)$ \\
\hline & $0.008^{* * *}$ & $0.006^{* *}$ & 0.000 & $0.001^{* *}$ & 0.001 \\
\hline Constant & $(3.46)$ & $(2.75)$ & $(0.59)$ & $(2.78)$ & $(1.16)$ \\
\hline & -1.424 & -0.233 & $-1.252^{* * *}$ & $0.498^{* *}$ & -0.159 \\
\hline Observations & $(-0.69)$ & $(-0.16)$ & $(-6.93)$ & $(2.74)$ & $(-0.93)$ \\
\hline No. clusters & 1,132 & 1,095 & 1,110 & 1,110 & 1,110 \\
\hline R ${ }^{2}$-within & 120 & 120 & 116 & 116 & 116 \\
\hline & 0.451 & 0.220 & 0.932 & 0.216 & 0.041 \\
\hline
\end{tabular}




\section{Tab. 6: The effects of ERM duration}

\begin{tabular}{|c|c|c|c|c|c|}
\hline & (1) & (2) & (3) & (4) & (5) \\
\hline & NOPAT & FCF & IC & ROIC & g rate \\
\hline \multirow[t]{2}{*}{ 1_ERM years } & -0.041 & -0.023 & $0.019^{*}$ & -0.009 & -0.015 \\
\hline & $(-0.93)$ & $(-0.39)$ & $(2.11)$ & $(-1.96)$ & $(-1.48)$ \\
\hline \multirow[t]{2}{*}{ 2_ERM years } & -0.042 & -0.041 & 0.020 & -0.009 & $-0.028^{*}$ \\
\hline & $(-0.81)$ & $(-0.63)$ & (1.95) & $(-1.55)$ & $(-2.00)$ \\
\hline \multirow[t]{2}{*}{ 3_ERM years } & -0.007 & 0.004 & 0.022 & -0.008 & -0.022 \\
\hline & $(-0.12)$ & $(0.05)$ & (1.69) & $(-1.13)$ & $(-1.61)$ \\
\hline \multirow[t]{2}{*}{ 4_ERM years } & 0.001 & -0.094 & 0.012 & 0.000 & -0.014 \\
\hline & $(0.02)$ & $(-0.68)$ & $(0.76)$ & $(0.05)$ & $(-0.68)$ \\
\hline \multirow[t]{2}{*}{ 5_ERM years } & -0.032 & 0.159 & 0.024 & -0.003 & -0.006 \\
\hline & $(-0.41)$ & $(1.78)$ & $(1.33)$ & $(-0.32)$ & $(-0.30)$ \\
\hline \multirow[t]{2}{*}{ 6_ERM years } & -0.043 & $0.400^{* *}$ & 0.018 & -0.005 & -0.028 \\
\hline & $(-0.53)$ & (3.28) & $(0.80)$ & $(-0.41)$ & $(-1.45)$ \\
\hline \multirow[t]{2}{*}{ 7_ERM years } & -0.102 & 0.087 & 0.022 & -0.016 & -0.038 \\
\hline & $(-1.12)$ & $(0.58)$ & $(0.99)$ & $(-1.35)$ & $(-1.68)$ \\
\hline \multirow[t]{2}{*}{ 8_ERM years } & -0.177 & 0.294 & 0.017 & -0.018 & -0.065 \\
\hline & $(-1.53)$ & (1.79) & $(0.59)$ & $(-1.09)$ & $(-1.38)$ \\
\hline \multirow[t]{2}{*}{ 9_ERM years } & -0.159 & 0.289 & 0.006 & -0.039 & -0.011 \\
\hline & $(-1.29)$ & $(1.53)$ & $(0.16)$ & $(-1.62)$ & $(-0.30)$ \\
\hline \multirow[t]{2}{*}{ 10_ERM years } & -0.122 & 0.205 & -0.006 & -0.019 & 0.022 \\
\hline & $(-0.92)$ & $(1.07)$ & $(-0.09)$ & $(-0.83)$ & $(0.52)$ \\
\hline \multirow[t]{2}{*}{ Size } & $0.807^{* * *}$ & $0.668^{* * *}$ & $1.085^{\star * *}$ & $-0.044^{\star *}$ & 0.029 \\
\hline & $(5.06)$ & $(5.62)$ & $(70.68)$ & $(-3.09)$ & (1.92) \\
\hline \multirow[t]{2}{*}{ Leverage } & $-0.179^{* *}$ & -0.165 & 0.006 & $-0.030^{*}$ & -0.014 \\
\hline & $(-3.15)$ & $(-1.46)$ & $(0.81)$ & $(-2.39)$ & $(-0.84)$ \\
\hline \multirow[t]{2}{*}{ Growth opp. } & $-1.655^{\star *}$ & $-1.652^{* * *}$ & 0.068 & $-0.239^{\star \star *}$ & 0.065 \\
\hline & $(-2.61)$ & $(-3.37)$ & $(1.27)$ & $(-4.18)$ & $(0.75)$ \\
\hline \multirow[t]{2}{*}{ Dividend policy } & 0.125 & 0.053 & 0.007 & $0.026^{*}$ & 0.010 \\
\hline & $(1.68)$ & $(0.77)$ & $(0.41)$ & $(2.35)$ & $(0.54)$ \\
\hline \multirow[t]{2}{*}{ Volatility } & $0.009^{\star * *}$ & $0.008^{\star \star \star}$ & 0.000 & $0.001^{* * *}$ & 0.001 \\
\hline & $(4.30)$ & $(3.74)$ & $(0.63)$ & $(3.58)$ & $(1.01)$ \\
\hline \multirow[t]{2}{*}{ Constant } & -0.783 & 0.468 & $-1.087^{* * *}$ & $0.520^{* * *}$ & -0.246 \\
\hline & $(-0.53)$ & $(0.43)$ & $(-7.86)$ & $(4.03)$ & $(-1.82)$ \\
\hline Observations & 1,657 & 1,612 & 1,644 & 1,644 & 1,644 \\
\hline No. clusters & 178 & 178 & 172 & 172 & 172 \\
\hline R2-within & 0.437 & 0.228 & 0.941 & 0.214 & 0.035 \\
\hline
\end{tabular}


effects of ERM use are negative for the first four years, but then they turn to positive. The coefficients are not statistically significant, though, except for 6 years of using ERM: the results show that after 6 years of using ERM, FCF is 0.4 percent higher compared to observations without ERM. The effects on NOPAT are not statistically significant, but their signs are mostly negative.

Taken together, it seems that the duration of ERM programs matters only for FCF. In the initial years after adoption, the effect on FCF is probably negative, but after that it seems to become positive. This finding is consistent with estimations in the literature that it takes three to five years to develop a mature ERM program (Fraser \& Simkins, 2010). The effects on the IC and the expected growth rate, however, seem to follow rather rapidly - within one to two years after ERM adoption.

\section{Discussion and Conclusion}

ERM programs are advocated as the solution for the failures and weaknesses of the traditional silo-based risk management in creating and protecting stakeholders' value (Kirkpatrick, 2009). Consistently also with the prevalent ERM literature, we argue that, if ERM is a value added activity, we should find that it is positively related to a set of value determinants. We test this on a sample of U.S. listed non-financial companies and find mixed evidence in support of our hypothesis.

The results indicate that companies with ERM have a higher level of invested capital, in comparison to non-ERM companies, but they invest less additional capital and with less success in terms of earnings/return, therefore, the effect on the expected growth rate is negative. One possible explanation for this is that ERM seems to effectively discourage companies to invest in high risk/high return type of projects. Instead, companies cautiously invest less capital and in less risky projects with smaller returns, which do not contribute to the fundamental value enhancement. This suggests that ERM companies are more conservative in their investment strategies and they pay much more attention to the down-side risk then to the company's up-side potential. Our study thus contributes to the existing body of knowledge about ERM by casting doubts on its supposed positive effects on the fundamental value drivers.
Moreover, due to its negative effect on the expected growth rate, it could even negatively affect the fundamental value. On the positive side, the study revealed that ERM is indeed associated with higher free cash flows. But it seems this takes place only after using ERM for around 6 years, while the effects on the invested capital and expected growth rate follow within a year or two after the implementation of ERM.

However, sinceall limitations of observational studies apply also in our case and the tested models are explorative in nature, the findings should be seen as indications rather than proofs of ERM causal effects. More theoretical and empirical research is needed to establish how ERM really works within a company and to whose benefit. We conducted this study from the viewpoint of shareholder's wealth maximization, which was the fundamental business goal for many past decades and for many companies. However, the global financial crisis brought more attention to corporate social responsibility and stakeholders' value protection. It is not responsible to maximize the wealth of shareholders by destroying value for other interested parties. Therefore, to determine whether ERM is a value added activity, and to whom it adds value, it is necessary to consider the different goals and risk appetites set in front of the companies that implement ERM. We interpret the implications for managerial practice in regional companies in this light as well. ERM is not an over-the-counter cure for businesses badly struck by a crisis, but it needs to be carefully prescribed to an individual company's business objectives and risk appetite.

We would like to thank the University of Zagreb for the financial support granted to the research project "Impact of Enterprise Risk Management on the Company's Financial Performance in a Period of the Global Financial Crisis". We are highly indebted to USC Marshall School of Business, University of Southern California, especially to Professor Duke Bristow for the help provided in using databases needed for our research as well as his helpful comments in early stages of our research. Thanks are extended to Professor Marina Dabic for her insightful comments, as well as delegates of the $13^{\text {th }}$ INFINITI Conference on International Finance for valuable suggestions how to improve our research. 


\section{References}

Allayannis, G., \& Weston, J. (2001). The Use of Foreign Currency Derivatives and Firm Market Value. The Review of Financial Studies, 14(1), 243-276. https://dx.doi.org/10.1093/ rfs/14.1.243.

Bank for International Settlement (BIS). (2008). Principles for Sound Liquidity Risk Management and Supervision. Basel: BIS. Retrieved from https://www.bis.org/publ/bcbs144.pdf.

Baxter, R., Bedard, J. C., Hoitash, R., \& Yezegel, A. (2013). Enterprise risk management program quality: Determinants, value relevance, and the financial crisis. Contemporary Accounting Research, 30(4), 1264-1295. https:// dx.doi.org/10.1111/j.1911-3846.2012.01194.x.

Bromiley, P., McShane, M. K., Nair, A., \& Rustambekov, E. (2014). Enterprise Risk Management: Review, Critique, and Research Directions. Long Range Planning, 48(4), 265-276. https://dx.doi.org/10.1016/j. Irp.2014.07.005.

Campbell, T. S., \& Kracaw, W. A. (1987). Optimal Managerial Incentive Contracts and the Value of Corporate Insurance. The Journal of Financial and Quantitative Analysis, 22(3), 315-328. https://dx.doi.org/10.2307/2330966.

Chartered Global Management Accountant (CGMA). (2015). Global State of Enterprise Risk Management: Analysis of the challenges and opportunities for improvement. Durham, NC: CGMA and Pool College of Management.

Damodaran, A. (2012). Investment Valuation: Tools and Techniques for Determining the Value of Any Asset. Hoboken, NJ: John Wiley \& Sons.

DeMarzo, P. M., \& Duffie, D. (1995). Corporate Incentives for Hedging and Hedge Accounting. Review of Financial Studies, 8(3), 743-771. https://dx.doi.org/10.1093/rfs/8.3.743.

Dolde, W. (1995). Hedging, leverage and primitive risk. Journal of Financial Engineering, 4(2), 187-216.

Eckles, D. L., Hoyt, R. E., \& Miller, S. M. (2014). The impact of enterprise risk management on the marginal cost of reducing risk: Evidence from the insurance industry. Journal of Banking \& Finance, 43, 247-261. https://dx.doi. org/10.1016/j.jbankfin.2014.10.006.

Financial Service Authority (FSA). (2008). Strengthening Liquidity Standards. London: FSA.

Fraser, J., \& Simkins, B. J. (Eds.). (2010). Enterprise Risk Management. Kolb Series in
Finance. Hoboken, NJ: John Wiley \& Sons.

Froot, K. A., Scharfstein, D. S., \& Stein, J. C. (1993). Risk Management: Coordinating Corporate Investment and Financing Policies. Journal of Finance, 48(5), 1629-1658. https:// dx.doi.org/10.1111/j.1540-6261.1993.tb05123.x.

Gay, G. D., \& Nam, J. (1998). The underinvestment problem and corporate derivatives use. Financial Management, 27(4), 53-69.

Géczy, C., Minton, B. A., \& Schrand, C. (1997). Why Firms Use Currency Derivatives. The Journal of Finance, 52(4), 1323-1354. https://dx.doi.org/10.1111/j.1540-6261.1997. tb01112.x.

Gordon, L. A., Loeb, M. P., \& Tseng, C-Y. (2009). Enterprise Risk Management and Firm Performance: A Contingency Perspective. Journal of Accounting and Public Policy, 28(4), 301-327. https://dx.doi.org/10.1016/j. jaccpubpol.2009.06.006.

Grace, M. F., Leverty, J. T., Phillips, R. D., \& Shimpi, P. (2015). The Value of Investing in Enterprise Risk Management. Journal of Risk and Insurance, 82(2), 289-316. https://dx.doi. org/10.1111/jori.12022.

Haushalter, G. D., Heron, R. A., \& Lie, E. (2002). Price Uncertainty and Corporate Value. Journal of Corporate Finance: Contracting, Governance and Organization, 8(3), 271-286. https://dx.doi.org/10.1016/S0929-1199(01)00043-8.

Haushalter, G. D. (2000). Financing Policy, Basis Risk, and Corporate Hedging: Evidence from Oil and Gas Producers. The Journal of Finance, 55(1), 107-152. https://dx.doi. org/10.1111/0022-1082.00202.

Hoshi, T., Kashyap, A., \& Scharfstein, D. (1991). Corporate Structure, Liquidity, and Investment: Evidence from Japanese Industrial Groups. Quarterly Journal of Economics, 106(1), 33-60. https://dx.doi.org/10.2307/2937905.

Hoyt, R. E., \& Liebenberg, A. P. (2011). The Value of Enterprise Risk Management. Journal of Risk and Insurance, 78(4), 795-822. https://dx.doi.org/10.1111/j.1539-6975.2011.01413.x.

Institute of International Finance (IIF). (2007). Principles of Liquidity Risk Management. Washington: IIF.

Kirkpatrick, G. (2009). The corporate governance lessons from the financial crisis. OECD Journal Financial Market Trends, 2009/1(96), 61-87.

Lam, J. (2001). The CRO Is Here to Stay. Risk Management, 48(4), 16-20.

Lam, J. (2003). Enterprise Risk Management: 
From Incentives to Controls. Hoboken, NJ: John Wiley \& Sons.

Liebenberg, A. P., \& Hoyt, R. E. (2003). The determinants of enterprise risk management: evidence from the appointment of chief risk officers. Risk Management and Insurance Review, 6(1), 37-52. https://dx.doi. org/10.1111/1098-1616.00019.

McShane, M. K., Nair, A., \& Rustambekov, E. (2011). Does Enterprise Risk Management Increase Firm Value. Journal of Accounting, Auditing and Finance, 26(4), 641-658. https:// dx.doi.org/10.1177/0148558X11409160.

McWilliams, A., \& Siegel, D. (2000). Corporate Social Responsibility and Financial Performance: correlation or misspecification? Strategic Management Journal, 21(5), 603609. https://dx.doi.org/10.1002/(SICl)10970266(200005)21.

Meulbroek, L. K. (2002). A Senior Manager's Guide. Journal of Applied Corporate Finance, 14(4), 56-70. https://dx.doi. org/10.1111/j.1745-6622.2002.tb00449.x.

Mian, S. (1996). Evidence on Corporate Hedging Policy. Journal of Financial and Quantitative Analysis, 31(3), 419-439. https:// dx.doi.org/10.2307/2331399.

Miloš Sprčić, D., \& Šević, Ž. (2012). Determinants of Hedging Decisions in Croatian and Slovenian large non-financial companies. Research in International Business and Finance, 26(1), 1-25. https://dx.doi. org/10.1016/j.ribaf.2011.05.001.

Minton, B. A., \& Schrand, C. (1999). The impact of cash flow volatility on discretionary investment and the cost of debt and equity financing. Journal of Financial Economics, 54(3), 423-460. https://dx.doi.org/10.1016/ S0304-405X(99)00042-2.

Modigliani, M., \& Miler, M. (1963). Corporate Income Taxes and the Cost of Capital: A Correction. The American Economic Review, 53(3), 433-443.

Nance, D. R., Smith, C. W., \& Smithson, C. W. (1993). On the determinants of corporate hedging. Journal of Finance, 48(1), 267-284. https://dx.doi.org/10.1111/j.1540-6261.1993.tb04709.x.

Nocco, B. W., \& Stulz, R. M. (2006). Enterprise Risk Management: Theory and Practice. Journal of Applied Corporate Finance, 18(4), 8-20. https://dx.doi.org/10.1111/j.17456622.2006.00106.x.

Organization for Economic Co-operation and Development (OECD). (2009). Corporate
Governance and the Financial Crisis: Key Findings and Main Messages. Paris: OECD.

Segal, S. (2011). Corporate Value of Enterprise Risk Management. Hoboken, $\mathrm{NJ}$ : John Wiley \& Sons.

Smith, C. W., \& Stulz, R. M. (1985). The Determinants of Firms Hedging Policies. The Journal of Financial and Quantitative Analysis, 20(4), 391-405. https://dx.doi. org/10.2307/2330757.

Stulz, R. (1984). Optimal Hedging Policies. The Journal of Financial and Quantitative Analysis, 19(2), 127-140. https://dx.doi. org/10.2307/2330894.

Titman, S., \& Wessels, R. (1988). The determinants of capital structure choice. The Journal of Finance, 43(1), 1-19. https://dx.doi. org/10.1111/j.1540-6261.1988.tb02585.x.

Vacik, E., Fotr, J., Špaček, M., \& Souček I. (2014). Scenarios and their application in strategic planning. E\&M Ekonomie a Management, 17(3), 118-135. https://dx.doi. org/10.15240/tul/001/2014-3-010.

Wooldridge, J. M. (2002). Econometric analysis of cross section and panel data. Cambridge, MA: MIT Press.

Mojca Marc, PhD University of Ljubljana Faculty of Economics Academic Unit for Management and Organization Slovenia mojca.marc@ef.uni-lj.si

Prof. Danijela Miloš Sprčić, PhD University of Zagreb Faculty of Economics and Business Department of Managerial Economics Croatia dmilos@efzg.hr

Marina Mešin Žagar, PhD University of Southern California USC Marshall School of Business Department of Finance United States of America and University of Zagreb Faculty of Economics and Business Department of Organization and Management Croatia mesin@marshall.usc.edu 


\section{Appendix A Examples of ERM companies}

AMERICAN ELECTRIC POWER - ERM implemented in 2002

(Form: Proxy Statement, Schedule 14A; Filing date: Mar-25-2002)

p. 7: "Our strategy is a balanced business model of regulated and unregulated businesses backed by assets, supported by enterprise-wide risk management and a strong balance sheet. We have been focused on the wholesale side of the business since it provides the greater growth opportunities. But, this is complemented by a robust regulated business that has a predictable earnings stream and cash flows. Strong risk management and a disciplined analysis of markets protected us from the California energy crisis and Enron's bankruptcy filing. "

p. 25: "Policies and procedures are established to identify, assess, and manage market risk exposures in our day to day operations. Our risk policies have been reviewed with the Board of Directors, approved by a Risk Management Committee and administered by a Chief Risk Officer. The Risk Management Committee establishes risk limits, approves risk policies, assigns responsibilities regarding the oversight and management of risk and monitors risk levels. This committee receives daily, weekly, and monthly reports regarding compliance with policies, limits and procedures. The committee meets monthly and consists of the Chief Risk Officer, Chief Credit Officer, V.P. Market Risk Oversight, and senior financial and operating managers. "

CORNING INC - ERM implemented in 2005

(Form: Proxy Statement, Schedule 14A; Filing date: Mar-03-2010)

p. 20: "Corning has a comprehensive risk management program that engages the Company's management/leadership and Board. Since 2005, the Company has employed an Enterprise Risk Management program ("ERM") that was modelled on the COSO II framework. Corning's ERM is a company-wide effort that involves the Board, management and Corning staff in an integrated effort to identify, assess and manage risks that may potentially affect the Company. A Risk Council, chaired by our Vice Chairman and Chief Financial Officer, Mr. Flaws, and composed of Corning management and staff, is a core governance element of the ERM." 


\section{Appendix B Example of a Non-ERM company}

Comment: when searching the CapIQ database in non-ERM companies' fillings there were no hits on the key words: enterprise risk management, ERM, strategic risk management, integrated risk management, Chief Risk Officer, risk committee etc.; the only hits were when searching 'risk management'. It can be seen from the fillings' clip that different corporate risks are managed "in silos", without considering and analyzing their aggregate impact on the company's goals. There is a lack of communication and cooperation between managers responsible for different risk categories, what makes the integration of risks hard to achieve.

\section{AT\&T Inc}

(Form: Proxy Statement, Schedule 14A; Filing date: Mar-10-2011)

p. 3: "The Board of Directors oversees and reviews certain aspects of the Company's risk management efforts.... In addition, under its charter, the Audit Committee reviews and discusses with management the Company's major financial risk exposures and the steps management has taken to monitor and control such exposures, including the Company's risk assessment and risk management policies. Members of the Finance and Compliance groups are responsible for managing risk in their areas and reporting regularly to the Audit Committee. The Company's chief audit executive meets annually in executive session with the Audit Committee. The chief audit executive reviews with the Audit Committee each year's annual internal audit plan, which is focused on significant areas of financial, operating, and compliance risk. The Audit Committee also receives regular reports on completed internal audits of these significant risk areas." 
Tab. A1: Industry structure of the sample at 2-digits SIC Code

\begin{tabular}{|c|c|c|c|}
\hline $\begin{array}{l}\text { 2-Digits } \\
\text { SIC Code }\end{array}$ & $\begin{array}{l}\text { Frequency } \\
\text { (firms) }\end{array}$ & $\%$ & $\begin{array}{c}\text { Cumula- } \\
\text { tive }\end{array}$ \\
\hline 1 & 1 & 0.39 & 0.39 \\
\hline 10 & 2 & 0.78 & 1.16 \\
\hline 13 & 12 & 4.65 & 5.81 \\
\hline 14 & 1 & 0.39 & 6.20 \\
\hline 15 & 1 & 0.39 & 6.59 \\
\hline 16 & 1 & 0.39 & 6.98 \\
\hline 20 & 13 & 5.04 & 12.02 \\
\hline 21 & 2 & 0.78 & 12.79 \\
\hline 23 & 2 & 0.78 & 13.57 \\
\hline 24 & 2 & 0.78 & 14.34 \\
\hline 25 & 2 & 0.78 & 15.12 \\
\hline 26 & 7 & 2.71 & 17.83 \\
\hline 27 & 1 & 0.39 & 18.22 \\
\hline 28 & 25 & 9.69 & 27.91 \\
\hline 29 & 3 & 1.16 & 29.07 \\
\hline 30 & 3 & 1.16 & 30.23 \\
\hline 33 & 4 & 1.55 & 31.78 \\
\hline 34 & 5 & 1.94 & 33.72 \\
\hline 35 & 14 & 5.43 & 39.15 \\
\hline 36 & 21 & 8.14 & 47.29 \\
\hline 37 & 10 & 3.88 & 51.16 \\
\hline 38 & 16 & 6.20 & 57.36 \\
\hline 39 & 2 & 0.78 & 58.14 \\
\hline 40 & 3 & 1.16 & 59.30 \\
\hline 42 & 1 & 0.39 & 59.69 \\
\hline
\end{tabular}

\begin{tabular}{|c|c|c|c|}
\hline $\begin{array}{l}\text { 2-Digits } \\
\text { SIC Code }\end{array}$ & $\begin{array}{l}\text { Frequency } \\
\text { (firms) }\end{array}$ & $\%$ & $\begin{array}{l}\text { Cumula- } \\
\text { tive }\end{array}$ \\
\hline 44 & 1 & 0.39 & 60.08 \\
\hline 45 & 2 & 0.78 & 60.85 \\
\hline 48 & 9 & 3.49 & 64.34 \\
\hline 49 & 25 & 9.69 & 74.03 \\
\hline 50 & 2 & 0.78 & 74.81 \\
\hline 51 & 4 & 1.55 & 76.36 \\
\hline 52 & 2 & 0.78 & 77.13 \\
\hline 53 & 8 & 3.10 & 80.23 \\
\hline 54 & 2 & 0.78 & 81.01 \\
\hline 55 & 2 & 0.78 & 81.78 \\
\hline 56 & 4 & 1.55 & 83.33 \\
\hline 57 & 2 & 0.78 & 84.11 \\
\hline 58 & 4 & 1.55 & 85.66 \\
\hline 59 & 4 & 1.55 & 87.21 \\
\hline 70 & 2 & 0.78 & 87.98 \\
\hline 72 & 1 & 0.39 & 88.37 \\
\hline 73 & 23 & 8.91 & 97.29 \\
\hline 75 & 1 & 0.39 & 97.67 \\
\hline 79 & 1 & 0.39 & 98.06 \\
\hline 80 & 2 & 0.78 & 98.84 \\
\hline 82 & 1 & 0.39 & 99.22 \\
\hline 87 & 1 & 0.39 & 99.61 \\
\hline 99 & 1 & 0.39 & 100.00 \\
\hline Total & 258 & 100 & \\
\hline
\end{tabular}




\section{Abstract}

\section{IS ENTERPRISE RISK MANAGEMENT A VALUE ADDED ACTIVITY?}

\section{Mojca Marc, Danijela Miloš Sprčić, Marina Mešin Žagar}

Enterprise risk management (ERM) programs are advocated as the solution for the failures and weaknesses of the traditional silo-based risk management in creating and protecting stakeholders' value. ERM encompasses activities and strategies which enable the company to systematically identify, measure, reduce or exploit, as well as to control and monitor the exposure to various types of corporate risks - strategic, financial, operational, reporting as well as compliance risks. By considering the interactive effects of different risk events, ERM offers a balance between the dual nature of risk - ensuring effective protection from threats and seizing the opportunities. This paper explores the association between ERM and a set of fundamental value determinants of S\&P 500 non-financial companies over the period from 2003 to 2012. Contrary to arguments found in the existing ERM literature, ERM companies did not experience a positive effect on most of the value drivers. We find that ERM is associated with lower expected growth rates within one to two years after the ERM adoption, indicating that ERM could even have a negative effect on the company's fundamental value. On the other hand, the study showed that ERM is associated with higher free cash flows after six years of its use. Our research thus found indicative evidence that ERM produces some positive effects over a longer term, as well as some negative immediate effects, which could be explained with the increased risk aversion of ERM companies. However, since the tested models are explorative in nature, more theoretical and empirical research is needed to establish how ERM really works within a company.

Key Words: Enterprise Risk Management, value drivers, value creation, non-financial companies.

JEL Classification: G30, G32.

DOI: 10.15240/tul/001/2018-1-005 